\title{
Aspects of the concept of theo-logy in the Old Testament: A discussion on J. Gericke
}

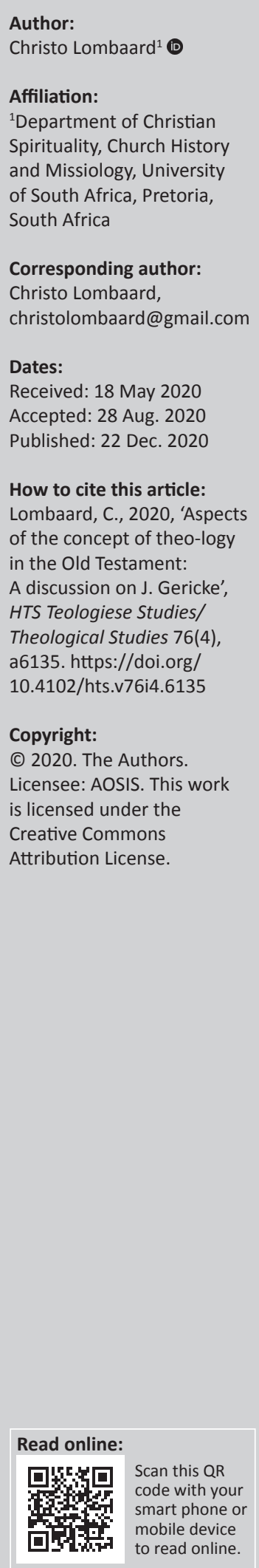

In this contribution, an aspect of the research of one of the more distinct voices in South African theology, Jaco Gericke, is contextualised and outlined. Although Old Testament Theology is an oft-enough reflected on topic by South African Bible scholars, such a theology is never written by South African scholars. However, Gericke's work tends in this direction. His work on God-talk, theo-logy, is the more important for our time, because it often relates to the kind of ideas popularly related to for instance God as creator in the Genesis texts. Gericke's work is however also attractive to intellectuals who work from the precepts of modernism or who are engaged in interdisciplinary research or who for purposes of decoloniality explore alternatives to Western scholarship. However, it is initially not easy for many readers to understand Gericke's contribution in combining philosophy and Old Testament studies, both practised on high levels. To this end, three instances of Gericke's argumentation are related as examples, with explanatory and interpretative comments made to demonstrate the high heuristic value of his contributions.

Contribution: Jaco Gericke's work can be characterised as theo-logy, in that he takes seriously the implications of modernism for 'God-talk'. He combines Philosophy and Old Testament Exegesis as academic enterprises, the intellectual productivity of which is demonstrable by means of examples.

Keywords: God concept; J Gericke; Old Testament studies; philosophy; interdisciplinarity; modernism; decoloniality.

\section{The local scene'}

In South Africa, much has been written about the subdiscipline of Old Testament Theology, such as the dissertation by Claassen (1996), analytical reviews (at times tangentially) related to this subdiscipline (such as those in the Prinsloo \& Vosloo 1987 edited volume) and proposals on employing the scholarly genre of Old Testament Theology to the benefit of preaching (for instance, Prinsloo 1994:358-376). A Theology of a single book could also be attempted (Prinsloo 1985, on Joel). There is a strong awareness in these publications of the issues related to the subdiscipline of Old Testament Theology as much as of the related Biblical Theology and History of Religions approaches in scholarly readings of the Hebrew Bible. However, no South African - thus mirroring the whole of the continent in this regard too - has yet written an Old Testament Theology.

Klaus Nürnberger has published two volumes, which at first glance seem to be Theologies: Theology of the biblical witness. An evolutionary approach (2002) and Biblical theology in outline: the vitality of the Word of God (2004), with the latter an altered, condensed version of the former, and with the 2004 version intended for a more popular readership. Both volumes take their analytical keys from the Old Testament: the patriarchs, the exodus with the taking of the land, kingdom, priesthood, covenant-law(-grace) and creation. However, on closer inspection (cf. Lombaard 2019/2020 for more substantial analytical remarks), these two volumes are principally systematic-theologically formed endeavours that draw on (older insights from) historical criticism. (They are thus in this respect similar in intent to another South African's undertaking in this regard, König's Hy kan weer en meer, 1982. Nürnberger's volumes also had a view to being contextually relevant to latter-day realities in South Africa.) These volumes, therefore, do not offer new insights on the Bible texts in the manner we have come to expect from a Theology.

1.This article is a revised version of a paper presented at the Pro Pent conference of $07-09$ September 2019 , held at the Bass Lake conference centre outside Pretoria, South Africa. Conference theme: 'Theology of Genesis (in the context of the Pentateuch)'. 
Old Testament theologies - the histories of which subdiscipline has been traced voluminously - can be broadly summarised as attempting, usually, one of three feats:

1. To lay bare, as it were, an inner coherence within the Hebrew Bible texts - of which good, although methodologically dissimilar, examples remain Eichrodt's influential Theology (1933-1939), which places the idea of covenant as centrepiece, and von Rad's still important, then-new history of traditions exegetical approach (1957);

2. To systematise a particular scholar's own understanding of the Old Testament, most often as a more or less end-ofcareer contribution, without the intent of doing anything akin to the first option - with Preuß's Theology (1991-1992) as a good instance of this approach; and

3. To analyse certain topics or themes as they occur or recur throughout the Hebrew Bible - with two methodologically different instances, Terrien's The elusive presence (1978) offering an approach that takes a single tack, which is to some measure generated externally to the Old Testament, and Routledge (2008) analysing a range of topics, which in greater measure present themselves as prominent within the texts of the Hebrew Bible.

South African Old Testament scholars, however, do not contribute to this genre of Hebrew Bible scholarship, in any of the three formats outlined above. For this, a number of explanations could be proposed, perhaps best formulated as a series of questions, given that the relative applicability of these explanations would differ from era to era, from institution to institution and from individual scholar to individual scholar:

- Is the reason - perhaps too banal - that the way scholarly work is funded in South Africa and is hence weighed within university bureaucracies in effect discourages such larger endeavours in favour of publishing more modest contributions? South African theological academia in general has namely excelled over recent decades in the highly compact publication genre of the research article, rather than the more wide-ranging monograph, which allows for more expansive investigations.

- Or could it be that South African exegetes feel themselves perhaps too timid for such an ambitious project as writing an Old Testament Theology? Such a systematising book indeed remains one of the most demanding of publication genres within Hebrew Bible scholarship, given the range of primary and secondary materials that have to be presented to a highly demanding audience. However, South Africans contributing commentaries to major international series (recently again, see Jonker 2013; Le Roux 2018; Snyman 2014) seems to some extent at least to mitigate such suspicions.

- Are we, as has often been said but seldom written, perhaps too engaged with debating the nature of the biblical text? Hence, also with the appropriate methods by means of which to exegete these texts (cf. Le Roux 1993)? Therefore, also with the manner of the Africanisation of Old Testament scholarship? On the latter, since 1976 already $^{2}$, with for instance Masenya (2016:380-394) who has been a prominent current voice in this regard (cf. Mosala 1989). Could it be that hermeneutics (for instance, diversely, Deist 1994; Page 2010) has in practice been more vital a South African enterprise amongst Bible scholars than attempting to discern the theology of, or the theologies in, the Old Testament? Differently formulated: has it been easier for Bible scholars to say how we (ought to) understand, than to say what we understand $?^{3}$

- Or is the reason more epistemic-creative, that none of us in the South African guild of Old Testament scholars have proposed an idea significantly innovative, either in insight or in approach, that it warranted something like an Old Testament Theology?

If the latter is the case, then perhaps Jaco Gericke is better positioned than many South African Old Testament scholars to write something along such lines. When Bosman (2015: 636-654) reviewed post-1994 trends in South African Old Testament scholarship, he characterised Gericke's work as 'creative and challenging' (Bosman 2015:646). What would the 'challenging' aspect of his work entail?

\section{Gerickety}

The word play in the title of this section is not to convey an implied evaluation of Gericke's academic contributions, which - to put my cards on the table - I regard very highly (as does, in some respects from a different theological background, Old Testament colleague Lerato Mokoena; cf. Mokoena 2019). Rather, the ricketiness of Gericke's conference presentations and academic publications here refers to the fragility of understanding him. What is it that Gericke tries to communicate? Many Old Testament scholars have expressed, always informally, at least initial surprise at the seeming (or perhaps unseemly) naïvite that accompanies Gericke's questioning, such as on 'What is a god?'

Quick private reactions to such questions posed by Gericke include that this kind of subject matter would fit better within the Science of Religion discipline of theology, for instance, and even then likely at an introductory level, or perhaps with an entry-level dictionary of theological terms (such as Deist 1984), rather than with proper Old Testament research, which assumes advanced theological insight. Such a question as for instance 'What is a god?' seems just too basic to fit with a discipline where there is already a strong shared sense of what terms such as Yahweh and Elohim denote, also in their complex historical relationship to one another (for instance Human 1999:491-505), and across the

2.The 1976 meeting of the Old Testament Society of South Africa, then a very small and Afrikaans, fully white male society (meant here simply descriptively, not as a negative evaluation, as has become the habit), decided at its Johannesburg meeting that the Africanisation of its scholarship should be an imperative.

3.If this is indeed the case, would it mean that epistemology has been silencing ontology? Put another way: has writing meta-theology been dominating the writing of theology? More broadly stated: in such circumstances, does the 'how to' drown out the 'what'? Has pragmatics muted the essentials? 
textual and historical panoramas of the Hebrew Bible and related texts.

Moreover, Gericke at times seems to have an anti-religious intent (in some ways perhaps akin to the famous Richard Dawkins's The god delusion, 2006) in the way he undermines not only concepts but also ways of thinking about them, in what could be termed a phenomenologically deconstructionist analysis of concepts in the Old Testament. Yet, in other instances Gericke works with an almost folklorist approach (at times self-acknowledged; cf. Gericke 2018a:267-282), reading sympathetically into the life world of the Bible text. This variance makes it difficult to fit Gericke's work into traditionally formed frameworks of reference within Old Testament scholarship, and is best accounted for by developments in his views (on which, see more below, in the closing section). ${ }^{4}$

The involved philosophy on which Gericke very ably draws, along with its accompanying terminology, which is not always part of the active range of technical terms amongst Old Testament scholars, often leads to an uncertain understanding of his contributions, at least initially.

Matters are not helped by the logic on which all practitioners of all sciences draw (despite insights from the sociology of knowledge, critiques from decoloniality theory and the increased cultural diversity of the guild of Hebrew Bible scholars internationally). This logic is in the mould of ancient Greece. Gericke conversely seeks to find the sensibilities within (or underlying) an ancient Semitic thought world, as the cultural birth bed of the Hebrew Bible texts. This he does whilst frequently warning that the Semitic-Hellenistic cultural worlds ought not reflexively be assumed to be oppositionally distinctive (cf. Gericke 2019a:1-16); yet, part of the foundations of Old Testament scholarship has long been, drawing on Lessing ([1777]1979):13), that one world (the modern) dare not simply be read into the other (the ancient). This matrix of sorts makes for a methodologically mystifying conundrum in any Old Testament reading in which dissimilar rationalities matter (cf. Lombaard 2015:5).

These complications all make for an initially brittle understanding of Gericke's work; colleagues often seem unsure, at least at first, about the aims of his contributions. In what follows, therefore, some of the key parts of Gericke's interpretative framework are identified. Because he is a unique figure within Old Testament scholarship, certainly within the South African context, my hope is that in doing so, his work could become more accessible to those who encounter him for the first time.

In addition, as one part of my work in Biblical Spirituality, I seek examples of figures who relate to the texts of the Bible in ways that demonstrate a variety of configurations of the faith-rationality / existential-interpretative / experientialanalytical matrices (cf. e.g. Lombaard 2019/2020, 2018:209-222, 2016:6-30, 2015b:1-13, 2012:1-5, Biernot \& Lombaard 2016:1-12, understood from within the implicit modernist-postmodernist-post-secularist cultural presuppositions of our time). This is not to impugn commitments on the part of my subject. ${ }^{5}$ Rather, I seek from his publications to understand how he approaches his subject matter, as I try to come to terms (although not always equally successfully - cf. Schreiber 2017:1-9) with the range of alternatives available around us.

Gericke's work is particularly productive to analyse when theology and the book of Genesis are under discussion. This is because it is in relation to this opening book of the canon that one of the major points of discussion in popular culture on the Bible and modern understanding keeps playing out: in relation to creation. Although, of course, the creation texts in Genesis form only a small part of its 50 chapters, two aspects bestow for the public mind greater than usual prominence on these Genesis chapters: that the Bible commences with these chapters and that for many lay religious readers that is where, therefore, 'revelation' starts (with the opening pericope of the fourth Gospel then underlining such an idea). It is, therefore, to a substantial extent here, in these opening verses of the Bible, that the edge of the reason 'and' or 'versus' faith polemic cuts most deeply in modern times. It is also here that theology as, specifically, 'God-talk' finds a major nexus in the work of Gericke.

South African Old Testament science has not remained unaffected by the "reason "and" faith or reason "versus" faith polemic', with Spangenberg perhaps the colleague whose scholarship has over many years been constituted most by this matter (cf. for instance Spangenberg 2019:107). However, in the writings of Gericke we find this matter constituted quite differently, and with greater philosophical depth than is the case with any other local exegetes. Perhaps contributions by the recently deceased Cornél du Toit come closest to this field of interest of Gericke, although from a systematictheological angle, rather than from a biblical scholarship angle (cf. for instance Du Toit 2000:506-526). Other Old Testament scholars whose writings are much influenced by readings in philosophy, include J.H. le Roux, H. Bosman and G. Snyman. However, as a scholar whose work on the Hebrew Bible has been foundationally constituted by a philosophical depth of reading, Gericke remains unmatched, certainly on the South African and broader African scene, and quite possibly on the global scene (with the possible exception of Seizo Sekine; cf., for instance, Sekine 2014). It is also on precisely this point that there has been appreciative academic reception of Gericke's contribution (Mtshiselwa \&

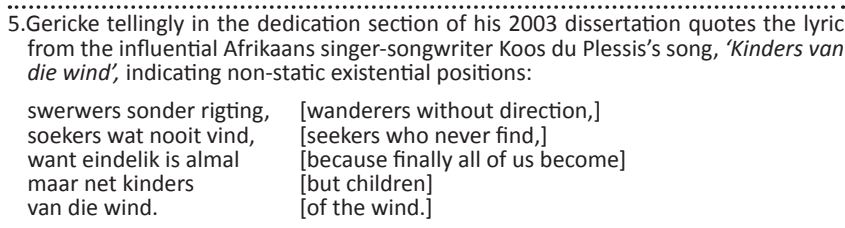
from the influential Afrikaans singer-songwriter Koos du Plessis's song, 'Kinders van die wind', indicating non-static existential positions:

swerwers sonder rigting, [wanderers without direction,] soekers wat nooit vind, [seekers who never find, want eindelik is almal [because finally all of us become] maar net kinders [but children] van die wind. [of the wind.] 
Mokoena 2018:1-6). Interesting parallel thoughts to Gericke's are found in Robert Carroll's two Wolf in the sheepfold books (1991, 1997), written however for a broader readership than academic circles and hence formulated in simpler terms, without the explicated philosophical interest.

Drawing on his dual academic interests, Hebrew Bible Scholarship and Philosophy, Gericke (2014:583-598) considers the Old Testament from a different angle than anybody else in South Africa, and with only a few discussion partners internationally. In what follows below, a series of three sections are abstracted from Gericke's works. Naturally, much more could be relayed here, given the extraordinary productiveness of Gericke on this topic as much as on many others. However, for the moment this will suffice to examine Gericke's contribution - that is, to look beyond the initially perceived naïveté: in fact, moving also beyond the famous second naïveté of Ricoeur (1967:350-352) as it relates to encountering Gericke's scholarship.

\section{Theo-logy à la Gericke}

'God-talk' - that is, theo-logy - is precisely the right terminology when referring to Gericke's work, because, although that is not his exclusive focus (cf. for instance Gericke 2017:315-335, 2018b:299-321, 2019b:1-6), hardly anybody says more about 'God' - the word, the concept, the usage, the resonances - than Gericke. This is not meant here in an evangelical-confessional sense, but with 'God' as the subject matter of scholarly investigation by Gericke. Given his continual philosophically informed self-relativising; Gericke readily recognises that there is no such position as a value-free view, in which a form of confessionality, of whichever kind, does not underlie any given approach; formulated slightly less academically, in all research, there is an aspect of 'sermonising'.

Three examples, extracted from selected quotations from Gericke's works, illustrate his manner of textual analysis. Noteworthy is the progression in his logic, and also his engagement with the text; it is not primarily what the text says (which would be, primarily, exegesis), but the underlying thought world of the text. On these three examples follows an interpretative discussion of the philosophical-theological world that Gericke inhabits (to some extent at least).

Example 1: From Gericke's second doctoral dissertation, Does Yahweh exist? A philosophical-critical reconstruction of the case against realism in Old Testament theology (2003), after arguing the matters at length, he concludes that in the Hebrew Bible:

- 'Yahweh is depicted in contradictory ways' (Gericke 2003:427);

- 'Yahweh is often depicted in ways that suggest he is not eternal, single, omnipotent, omniscient, immutable, precognisant, omnipresent and omnibenevolent' (Gericke 2003:428);

- 'Yahweh's own knowledge about the world ... seem alltoo-human. What Yahweh takes for granted as being eternally and objectively real, valid and normative are no more than the superstitious, historically relative and culturally contingent beliefs of his speechwriters. This ... unmasks Yahweh ...' (Gericke 2003:428);

- 'Yahweh's own cult and the texts allegedly witnessing to his supposed revelation contain numerous elements of myth ... in many instances, the Old Testament authors have borrowed extensively from pagan literature ... Since it is on these grounds that the deities of other religions are usually dismissed as being demonstrably fictitious entities, consistency demands that the depictions of Yahweh must share the same fate' (Gericke 2003:428);

- 'it might actually be possible to empirically falsify realism regarding the ontological status of Yahweh-as-depicted in the Old Testament texts by showing that the world described therein has no extra-textual counterpart' (Gericke 2003:428);

- 'Since texts purporting to be history are demonstrably nothing of the sort, realism collapses. The so-called history in which Yahweh supposedly revealed himself is no more than historical fiction and, therefore, Yahweh never really appeared, acted and spoke as depicted in the Old Testament texts' (Gericke 2003:429); and

- 'the ontological implications of the all-too-human origin, nature and development of both Yahwism as a religion and the Old Testament ... exhibit a marked tendency for repressing the fact that realism with regard to the ontological status of Yahweh is problematic and has, in fact, collapsed' (Gericke 2003:429).

From this, it follows (Gericke 2003):

... if Yahweh-as-depicted in certain texts does not exist, the deity Yahweh who in other texts - when speaking in the first person refers to the former texts as if realism was justified is also unmasked as a character of fiction.

... the way in which the case against realism was articulated has a domino effect operative in the deconstruction of realism in all Old Testament texts. The Old Testament texts, diverse though they may be, contain a substantial amount of inter-textual allusions. Moreover, later texts assume the validity of realism regarding at least some of the depictions in the former. As a result of this state of affairs, the collapse of realism regarding the whole follows inevitably with the invalidation of realism regarding some of its parts.

Ultimately, since the depictions of Yahweh that were the main interest in this study are from the Old Testament texts, if Yahwehas-depicted in these texts does not exist and the Old Testament was our only epistemological source, all grounds for believing in the existence of Yahweh per se disappears. To continue holding on to such a belief would be both irrational and unethical since the retention of a realist ideology is not only bereft of evidence but actually against the evidence. (pp. 431-432)

Example 2: From Gericke's book, The Hebrew Bible and philosophy of religion (2012):

[T] he biblical scholar can ask historical philosophical questions such as: Can a logically coherent conception of Yhwh in a given biblical text be articulated? What does a given biblical text 
assume regarding the ultimate source for humans ideas of the divine? What does a given text presuppose or imply about the range of Yhwh's power? How does a given text understand the nature of his knowledge? According to a given creation account, what is divine creation assumed to be? How, according to a given text, is Yhwh assumed to be related to time? These are the sorts of questions that could typically be investigated in a philosophical theology of the Hebrew Bible. (p. 294)

But:

Ironically, the same biblical theologians who decry the use of philosophical concepts show no end to displaying their own addiction to the distortive anachronism known as 'perfect being' theology. On this view, one counts a being as divine only if it is maximally great. That is to say, only if this being possesses the greatest array of possible great-making properties. The term 'great-making properties' is generally used in the literature to signify those properties that it is intrinsically better to have than to not have. (p. 296)

Hence:

The problem here, as every biblical theologian should know, is that what counts as great-making properties in ancient Israelite religion were not stable throughout the history of religion: different conceptions of Yhwh in the Hebrew Bible have incommensurable ideas on the matter. Moreover, many of these differ radically from conceptions of deity in classical theism. In this regard many an Old Testament theologian has assumed, asserted, or implied that Yhwh is believed to instantiate what philosophical theologians refer to as 'maximal greatness', in other words, that Yhwh is believed to be omnipotent, omniscient, omnipresent, omnibenevolent, and so on. The fact of the matter is that these terms are part of a metalanguage that is completely out of place in many biblical narratives. While some texts in the Hebrew Bible may endorse something vaguely approximating these attributes as they are popularly understood, there are many textual contexts in which this is by implication not the case. (pp. 296-297)

Example 3: From Gericke's article, 'What is your God? A classic philosophical perspective on ילא-X theophory in the Hebrew Bible' (2016):

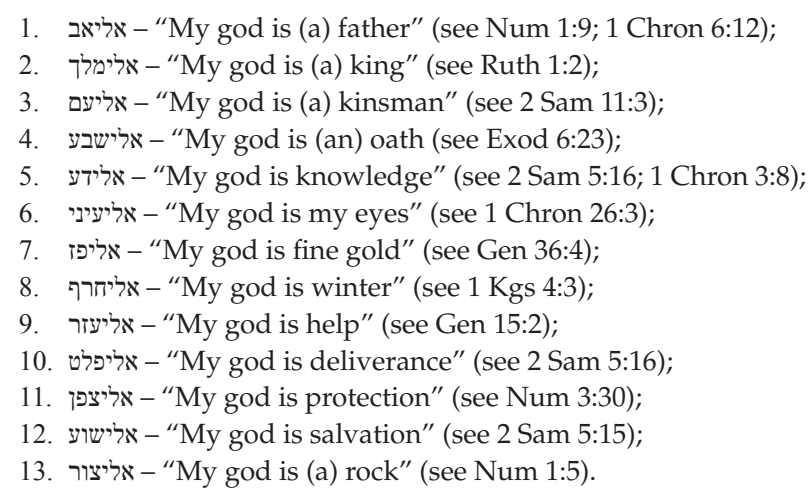

From this overview of divine metaphors (Gericke 2016:2) follows the question (Gericke 2016:3): 'can these personal names, from a philosophical perspective, be said to answer the question of what a god was?'

On this is concluded, after a highly technical argumentation (Gericke 2016):
Based on an Aristotelian (philosophical) perspective on a particular set of data it is concluded that the onomastica involve the predication of accidental properties of divinity only, and this despite having the prima facie appearance of being identity statements involving essential predication or definition ...

Hence names of the sub-type 'My אל $(\mathrm{S})$ is x (P)' cannot be said to signify what-it-is with reference to an אל אל but rather simply one property of being that particular אל (p. 12)

In what follows, these three illustrations of Gericke's approach to the text are described, to come to an understanding of what it is that Gericke does when he reads the Hebrew Bible.

\section{Characterising Gericke's engagement with the text}

As was noted before rendering the three examples above, the way in which Gericke applies interpretative logic to the text of the Hebrew Bible draws one's attention. His approach is unusual and in many respects distinctive. Gericke namely does not try, in these instances above, to conduct exegesis in the usual ways, which would customarily include at least one of three aims:

- Seeking to ascertain what the text had tried to say in its ancient context(s), and at times additionally, from there possibly to discern continued meaning of the text for parallel or analogous situations in our time;

- Attempting to trace the development of the text, often then also in relation to the development of related texts to come to a broader theory of historical textual development; or

- Identifying underlying political, geographic, sociological or other factors that play a role within the text or in its origination-elaboration.

These matters are all assumed by Gericke; they are neither suppressed nor circumvented in his scholarship, which is essential to realise, but rather they are directly drawn on in order to reach towards something different. The latter includes, as central contributions:

- That God as presented in a contradictory variety of ways in the assembly of texts in the Hebrew Bible does not fit with the valid, rational precepts from ancient Greek logic (although the distinction should not be made too sharply - Gericke 2019a:1-16), expressed also in modern intellectual understandings as much as in popularly assumed truths about the nature of divinity;

- That presentations on or from the texts of the Hebrew Bible lead to unsatisfying attempts at systematising a coherent view of God and should be recognised as such on the bases of these precepts or understandings or truths;

- That the God of the Old Testament is unsayable, not in this case meant in the sense that scholars of mysticism would frequently defer to in order to refer to the divine, but according to the standard precepts or understandings or truths by which scholarship is practised, including 
theological scholarship, and daily lives lived. That there was something underlying the God-talk in the Hebrew Bible is clear, but it is wrought and does not reflect the coherence of thought to be expected of God-talk and is, by implication, awkward to draw on and employ with integrity.

Almost like an existential psychologist of the text, Gericke enquires after the philosophical underpinnings to the Hebrew Bible, on which it is implicitly based in order to be what it is. Gericke seeks to show the implied foundations, namely that they are not there as we would assume them to be. We thus see in Gericke's work (modern) rationality attempting on its terms (which largely equals 'our' terms, as the guild of scholars of the Old Testament) to identify the (ancient) metaphysics that enabled what was said in the biblical texts (cf., however, Gericke 2019a:1-16, with Barr 1961 the most famous publication along these lines). As with a psychologist telling a client in terms different to those that the client would normally use what it is that constitutes the basic assumptions underlying their sensibilities, Gericke indicates in language and concepts that would be foreign to these texts, the fundamental suppositions that are typically attributed to it.

Such indications by Gericke are not dependent on his intentions, which had earlier been implicitly to demonstrate the problems inherent to religiosity and later simply to understand and describe. The distinction between a prescriptive and descriptive approach, usually employed in the subdiscipline of Old Testament Ethics (for instance, recently again Collins 2019:14; cf. Gericke 2010:261-282), may therefore be loosely applied to Gericke's intellectual intent, with 2008 as a rough indication of this change. Although Gericke had employed in this regard the concept of a 'third naïveté' on moving beyond the certainties of non-faith and faith, alluding to Ricoeur's famous second naïveté (Ricoeur 1967:349), he has done so only orally, and not in publication. ('Third naïveté' does indeed occur in academic literature, although it is often poorly described. The exception to this trend is the use of 'third naïveté' by Chauvet 1995:265 and taken up by, for instance, Mannion 2016:17; Mongrain 2006:137-141). 'Loosely applied', because taken overall, Gericke's approach can be characterised as phenomenologically exploratory, in the sense that he tries to illustrate the philosophical, more accurately, the culturaltheological hinterland to the text, unstated by the Bible text itself, which is largely unfathomable within our thought world. This certainly lies at the boundaries of scholarship, as the limits of our understanding are explored, on the possible threshold of something new.

For readers well versed singly in the precepts of modernism, for readers who appreciate such more abstract description, perhaps for interdisciplinary research purposes in their engagement with the biblical text, and for readers engaged in the decoloniality track of exploring alternatives to Western scholarship, this method of Gericke would well seem to be more dispassionate, that is, less existentially threatening to their positions and directions than the more common exegetical engagements. As difficult to gauge as Gericke's scholarship may prove for exegetes in the more traditional modes of textual engagement, at least initially, it has the value of seeming more welcoming to readers from such backgrounds and could hence draw a different readership. No wonder then that Gericke contributed to an introduction to the Old Testament explicitly geared towards such a readership, titled The Scriptures of Ancient Judaism: A Secular Introduction (Jigoulov, Gericke \& Jacobs 2020).

This approach by Gericke furthermore renders his writings immediately recognisable - which is always a good sign when engaging on a significant novel trajectory of research (Bosman 2015:646), in what could perhaps, in admittedly here an optimistic spirit, become part of building an influential school of research. In research on the book of Genesis and on the 'God-talk' taken up in these opening chapters to the Bible, that is certainly valuable, as the disciplines of theology engage ever more with academic disciplines that fall outside of its usually assumed range. These disciplines undertake the even more difficult task of taking theology seriously, and what it has to offer academia and society in their (related) journeys of understanding.

\section{Acknowledgements Competing interests}

The author declares that he has no financial or personal relationships that may have inappropriately influenced him in writing this research article.

\section{Author's contributions}

C.L. is the sole author of this research article.

\section{Ethical consideration}

This article followed all ethical standards for a research without direct contact with human or animal subjects.

\section{Funding information}

This research received no specific grant from any funding agency in the public, commercial or not-for-profit sectors.

\section{Data availability statement}

Data sharing is not applicable to this article as no new data were created or analysed in this study.

\section{Disclaimer}

The views and opinions expressed in this article are those of the author and do not necessarily reflect the official policy or position of any affiliated agency of the author.

\section{References}

Barr, J., 1961, The semantics of Biblical language, Oxford University Press, Oxford. Biernot, D. \& Lombaard, C., 2016, 'The prayers, tears and joys of Don Cupitt: Nonrealist, post-Christian spirituality under scrutiny', HTS Teologiese Studies/ Theological Studies 74(3), 1-12. https://doi.org/10.4102/hts.v74i3.4971 
Bosman, H.L., 2015, 'Ants, spiders or bees ... and ticks? A typology of Old Testament scholarship in South Africa since 1994 within its African context', Old Testament Essays 28(3), 636-654. https://doi.org/10.17159/2312-3621/2015/v28n5a5

Carroll, R., 1991, Wolf in the sheepfold. The Bible as problematic for Christianity, SPCK, London.

Carroll, R., 1997, Wolf in the sheepfold. The Bible as problematic for Theology, SPCK, London.

Chauvet, L.-M., 1995, Symbol and sacrament: A sacramental reinterpretation of Christian existence, The Liturgical Press, Collegeville, PA.

Claassen, G.F., 1996, 'Die kanoniese benadering van BS Childs', DD proefskrif, Universiteit Van Pretoria, Pretoria.

Collins, J.J., 2019, 'The relevance of the Old Testament for contemporary ethics', Journal of Ethics in Antiquity and Christianity (1), 10-16.

Dawkins, R., 2006, The God delusion, Bantam Press, London

Deist, F., 1984, A concise dictionary of theological terms, Van Schaik, Pretoria.

Deist, F., 1994, Ervaring, rede en metode in Skrifuitleg. ' $n$ Wetenskapshistoriese ondersoek na Skrifuitleg in die Ned. Geref. Kerk 1840-1990, Raad vir Geesteswetenskaplike Navorsing, Pretoria.

Du Toit, C., 2000, 'Evolutionary biology as a link between religion and knowledge', HTS Teologiese Studies/Theological Studies 56(2\&3), 506-526. https://doi. org/10.4102/hts.v56i2/3.1750

Eichrodt, W., 1933-1939, Theologie des Alten Testaments (I-III), Hinrichs, Leipzig.

Gericke, J., 2010, 'Descriptive varieties of philosophical commentary', Old Testament Essays 23(2), 261-282.

Gericke, J., 2012, The Hebrew Bible and philosophy of religion, Society of Biblical Literature, Atlanta, GA.

Gericke, J., 2014, 'Is there philosophy in the Hebrew Bible? Some recent affirmative perspectives', Journal for Semitics 23(1), 583-598. https://doi.org/10.25159/1013perspectives,
$8471 / 3507$

Gericke, J., 2016, 'What is your God? A classic philosophical perspective on אלי-X theophory in the Hebrew Bible', Journal for Semitics 25(1), 1-14. https://doi. org/10.25159/1013-8471/2523

Gericke, J., 2017, 'The meaning of Moses' life: An analytic and comparative philosophical perspective', Old Testament Essays 30(2), 315-335. https://doi. org/10.17159/2312-3621/2017/v30n2a8

Gericke, J., 2018a, 'The folk-metaphysics of relations in Old Testament extensions of generic divinity', in D. Bertini \& D. Magliorini (eds.), Relations. Ontology and philosophy of religion, pp. 267-282, Mimesis, Milan.

Gericke, J., 2018b, 'The concept of philosophy in post-apartheid Western historical overviews of 'South African Old Testament scholarship', Old Testament Essays 31(2), 299-321. https://doi.org/10.17159/2312-3621/2018/v31n2a3

Gericke, J., 2019a, “"My thoughts are (not) your thoughts." Transposed second-order thinking in the Hebrew Bible', Journal for Semitics 27(1), 1-16. https://doi. org/10.25159/1013-8471/4217

Gericke, J., 2019b, 'New perspectives on Old Testament oneirocritic texts via the philosophy of dreaming', HTS Teologiese Studies/Theological Studies 75(3), 1-6. philosophy of dreaming', HTS Teologies
https://doi.org/10.4102/hts.v75i3.5001

Gericke, J.W., 2003, 'Does Yahweh exist? A philosophical-critical reconstruction of the case against realism in Old Testament theology', PhD dissertation, University of Pretoria, Pretoria.

Human, D.J., 1999, 'Aspects of monotheism: A continued debate', Old Testament Essays 12(3), 491-505.

Jigoulov, V., Gericke, J. \& Jacobs, S.L., 2020, The scriptures of ancient Judaism A secular introduction, Cognella, San Diego, CA.

Jonker, L.C., 2013, 1 \& 2 Chronicles, Understanding the Bible Commentary Series, Baker Books, Grand Rapids, MI.

König, A., 1982, Hy kan weer en meer, N.G. Kerkboekhandel, Pretoria.

Le Roux, M., 2018, Richteren, De Prediking van het Oude Testament, Kok Boekencentrum Uitgevers, Utrecht.

Le Roux, J.H., 1993, A story of two ways: Thirty years of Old Testament scholarship in South Africa, Verba Vitae, Pretoria.

Lessing, G.E., [1777]1979, 'Über den Beweis des Geistes und der Kraft', in H. Göpfert (Hrsg.) (ed.), Werke, 8. Bd.: Theologiekritische Schriften III, Philosophische Schriften, pp. 9-14, Hanser, München.

Lombaard, C., 2015a, 'Mysticism and/in the Old Testament: Methodological orientation and a textual example', HTS Teologiese Studies/Theological Studies 71(1), 1-5. https://doi.org/10.4102/hts.v71i1.2813
Lombaard, C., 2015b, 'Hol(e)y texts; Hol(e)y lives: On the psalms and spirituality. With particular attention to Thessalonia DePrince, Thomas Merton and Beat Weber described, compared and evaluated', Scriptura 114(1), 1-13. https://doi. described, compared and
org/10.7833/114-0-1139

Lombaard, C., 2016, 'Spirituality and culture in interaction: The illustrative recurring debate on the role of the Oldest Testament in Christian theology and broader culture', in M. Miner \& M. Dowson (eds.), Proceedings of the spirituality, culture and well-being conference, Inaugural Conference of the Lumen Research Institute, axd well-being conference, Inaugural Conference of the Lumen Research Institute, Excelsia College \& Indiana Wesleyan University, Lumen Research Institute/Centre
for Human Interaction, Learning and Development, Sydney, 4th-5th October for Human Inter pp. 6-30.

Lombaard, C., 2018, “'Sing unto the LORD a new song" (Ps. 98:1): Aspects of the Afrikaans punk-rock group Fokofpolisiekar's musical spirituality as rearticulated aspects of the 1978 Afrikaans Psalm en Gesangeboek', in C.J. Kaunda \& aspects of the 1978 Afrikaans Psalm en Gesangeboek', in C.J. Kaunda \&
R.R. Hewitt (eds.), Who is an African? Race, identity, and destiny in post-apartheid R.R. Hewitt (eds.), Who is an African? Race, identity, and dest
South Africa, pp. 209-222, Lexington Books, Lanham, ML.

Lombaard, C., 2019/2020, 'Biblical witness and economy in the writings of Klaus Nürnberger', paper presented at the 41st Annual Congress of the Association for the Study of Religion in Southern Africa (conference theme: Religion and Economy), 4-5 September 2019, held at the University of South Africa, Publication forthcoming: HTS Teologiese Studies/Theological Studies special edition, 'Christianity as a Change Agent in the 4th Industrial Revolution World (focused on
South Africa)', 2020.

Mannion, G., 2016, 'Thinking outside the ecumenical box: Assisi 2012 - Story, method, and beyond', in G. Mannion (ed.), Where we dwell in common: The quest for dialogue in the twenty-first century, pp. 3-24, Palgrave Macmillan, Basingstoke.

Masenya(ngwan'aMphahlele), M., 2016, “"Foreign” on own home front? Ruminations from an African-South African Pentecostal biblical scholar', in V. Synana, A. Yong \& J.K. Asamoah-Gyadu (eds.), Global renewal Christianity: Spirit-empowered movements: Past, present and future, pp. 380-394, Charisma Media, Lake Mary, FL.

Mokoena, L.L.D., 2019, 'Another meaning is possible: A re-reading of hebel in Qohelet', PhD Old Testament dissertation, University of Pretoria, Pretoria.

Mongrain, K., 2006, Worship in spirit and truth: Louis-Marie Chauvet's sacramental reading of John 4:21-24', in C. Helmer \& C.T. Higbe (eds.), The multivalence of biblical texts and theological meanings, pp. 125-144, Society of Biblical Literature, Atlanta, GA.

Mosala, I.J., 1989, Biblical hermeneutics and Black Theology in South Africa, Eerdmans, Grand Rapids, MI.

Mtshiselwa, N. \& Mokoena, L., 2018, 'Humans created God in their image? An anthropomorphic projectionism in the Old Testament', HTS Teologiese Studies/ Theological Studies 74(1), 1-6. https://doi.org/10.4102/hts.v74i1.5017

Nürnberger, K., 2002, Theology of the biblical witness. An evolutionary approach, LIT Verlag, Münster.

Nürnberger, K., 2004, Biblical theology in outline: The vitality of the word of God, Cluster Publications, Pietermaritzburg.

Page, H.R., 2010, The Africana Bible. Reading Israel's scriptures from Africa and the African diaspora, Fortress Press, Minneapolis, MN.

Preuß, H.-D., 1991-1992, Theologie des Alten Testament, Kohlhammer, Stuttgart.

Prinsloo, G.T.M., 1994, 'Die rol van Ou Testament Teologie in die prediking', Skrif en Kerk 15(2), 358-376. https://doi.org/10.4102/ve.v15i2.1102

Prinsloo, W.S., 1985, The theology of the book of Joel, De Gruyter, New York, NY.

Prinsloo, W.S. \& Vosloo, W., 1987, Ou Testament Teologie: Gister, vandag en môre, NG Kerkboekhandel, Pretoria.

Ricoeur, P., 1967, The symbolism of evil, Beacon Press, Boston, MA.

Routledge, R., 2008, Old Testament theology: A thematic approach, Apollos, Nottingham.

Sekine, S., 2014, Philosophical interpretations of the Old Testament, De Gruyter, Berlin.

Schreiber, D.A., 2017, 'Lombaard's categorical invitation for minority dissent against "suspicion": How real is the "religious" in post-secular context?', Verbum et Ecclesia 38(1), 1-9. https://doi.org/10.4102/ve.v38i1.1722

Snyman, S.D., 2014, Malachi, Historical Commentary on the Old Testament, Peeters, Leuven.

Spangenberg, I.J.J., 2019, 'Richard Dawkins, Philip Kennedy and the Augustinian paradigm of Christianity', HTS Teologiese Studies/Theological Studies 75(3), 1-7. https://doi.org/10.4102/hts.v75i3.5084

Terrien, S., 1978, The elusive presence. Toward a new Biblical Theology, Harper \& Row, San Francisco, CA.

Von Rad, G., 1957, Die Theologie der geschichtlichen Überlieferungen Israels, Chr. Kaiser Verlag, München. 